\title{
Arable Land and Climate
}

\author{
Khalidullin 0* \\ Ecology Professor. Kazakhstan \\ *Corresponding author: Khalidullin O, Ecology Professor. Kazakhstan
}

\begin{tabular}{|c|c|}
\hline ARTICLE INFO & ABSTRACT \\
\hline Received: 幽 September 30, 2019 & Citation: Khalidullin O. Arable Land and Climate. Biomed J Sci \& Tech Res 21(5)-2019. \\
\hline Published: 慧October 09, 2019 & BJSTR. MS.ID.003658. \\
\hline
\end{tabular}

\section{Introduction}

The findings of the study indicate that bare soils, where no vegetation is allowed, except for crops, they are more prone to erosion by air and water, compaction and gradual deterioration. Such areas in the world are now about $11 \%$ of all land. Bare soils change the quality of water at the moments of its movement in the soil and after evaporation in the atmosphere. On such land, the natural func tion of water changes. Water changes its properties. Throughout the season, exposed soil, exposed to open solar heating, evaporates the moisture much faster. Evaporative intensification occurs after each natural and artificial irrigation. The path of its transformations is shortened, the variety of transformations disappears. The natural microflora and micro fauna of the whole cultivated soil disappear, and with it all other living creatures (Figure 1).

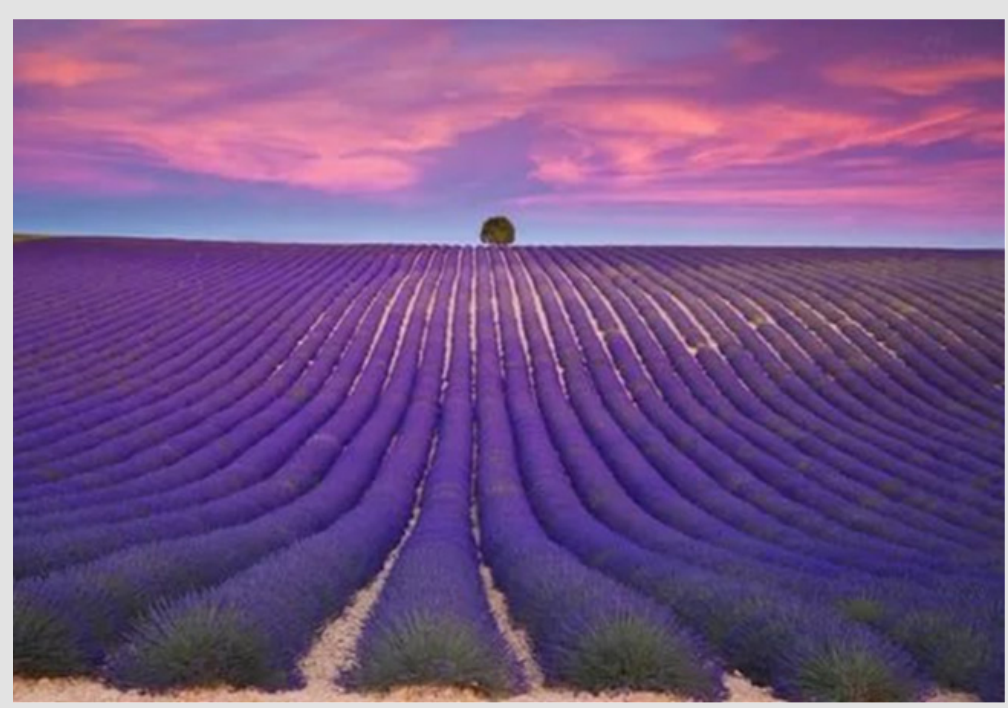

Figure 1.

The transfer of moisture from one subject of flora and fauna to another creates its own special environment in which a great many different fumes make up the very essence of the life of each area. Water, making a natural cycle on an uncultivated natural area, carries a great many vapors from a wide variety of sources into the atmosphere. Each element of the biota creates its own individual bouquet of exuded emissions and fumes, for example, odors, volatile production. These are the conditions over millions of years that created the water and climate of the Earth. The destruction of this idyll by arable land, landfills and ore landfills, reservoirs led to the 
creation of artificial fumes. Evaporation of water from technological and municipal processes gives an even greater increase. The total volumes of such vapors become prevailing over natural ones. Their

\section{ISSN: 2574-1241}

DOI: 10.26717/BJSTR.2019.21.003658

Khalidullin 0. Biomed J Sci \& Tech Res

This work is licensed under Creative Commons Attribution 4.0 License

Submission Link: https://biomedres.us/submit-manuscript.php quality, speed and volume create a new cycle of water, devoid of meaning and any norms. Hence natural disasters, as harbingers of global catastrophe.

$\begin{array}{ll}\text { BIOMEDICAL } & \text { Assets of Publishing with us } \\ \text { RESEARCHES } & \text { - Global archiving of articles } \\ & \text { - Immediate, unrestricted online access } \\ & \text { - Rigorous Peer Review Process } \\ \end{array}$

